Petrenko Nataliia,

Postgraduate Student, Kyiv National University of Trade and Economics, Kyiv, Ukraine

ORCID: 0000-0002-9873-2327

Researcher ID: O-4949-2018

\title{
ANTI-CORRUPTION STATE POLICY: PROBLEMS AND PROSPECTS OF DEVELOPMENT
}

The article analyzes the current state of the state anti-corruption policy in the sphere of combating corruption and peculiarities of its implementation. The set of general directions of anti-corruption policy is highlighted. The state of formation and implementation of anti-corruption policy in Ukraine, its directions and ways of implementation are investigated. Topical issues of further implementation of anticorruption measures and development of legislation are considered, ways of their solution are suggested.

Keywords: corruption, anti-corruption, anti-corruption policy, anti-corruption reform, realization of state anti-corruption policy.

Петренко Наталія. Антикорупційна державна політика: проблеми та перспективи розвитку. У статті проаналізовано сучасний стан державної антикорупиійної політики у сфері протидії корупџіï та особливості ї̈ реалізації. Виділено сукупність загальних напрямів антикорупиійної політики. Досліджено стан формування та реалізачії антикорупиійної політики в Україні, ї̈ напрями та шллхи здійснення. Розглянуто актуальні питання подальшої реалізаиії антикорупиійних заходів та розвитку законодавства, запропоновано шляхи їх вирішення.

Ключові слова: корупчія, протидія корупиії, антикорупџійна політика, антикорупиійна реформа, реалізаиія державної антикорупџійної політики

Relevance of research topic. The strategic goal of anti-corruption policy is to counter corruption at the national level, at the same time, there is no consensus on the creation of effective mechanisms for combating corruption. Corruption, according to well-known European researcher Leslie Holmesit is one of the most global problems, above the extreme of poverty, unemployment, rising food costs, energy, threatening climate change and terrorism. Its value in today's world cannot be underestimated, because it is one of the leading causes of poverty worldwide (Holmes L., 2015, p. 4). 
Formulation of the problem. One of the most urgent issues of modern development of Ukraine is the need to intensifying the fight against corruptionand its attribution to the integral component of the general and overarching domestic policy of the state. At the same time, the primary task is to develop and substantiate mechanisms for combating corruption to apply positive practices in this field to Ukrainian realities,improvement of the state anti-corruption policy.Formation of an effective mechanism for combating corruption is conditioned by objective and subjective factors of the country's social development.It should be noted that during the independence of our country failed to form an effective system for combating corruption.Non-systematic law enforcement reorganizations did not produce the desired result.That is why today, as never before, the question of creating improvements in the mechanisms of anti-corruption policy and really proper anticorruption institutions has been raised.

Analysis of recent researches and publications. Problems of preventing and overcoming corruption study by scientists, the public, international organizations, at the same time, there is no consensus on creating an effective mechanism for combating corruption. There are several approaches to examining anti-corruption policies as a subject of study: essence, content, concepts were studied by V. Bakumenko, V. Bashtannik, V. Solovyov.Political and administrative aspects of anti-corruption policy formulation - I. Gritsyak, A. Savkov, O. Sushinsky. In terms of the international legal approach, anti-corruption policy was investigated by M. Lakhizh, L. Prokopenko, O. Rudenko, and V. Solovykh.The economic and legal approach was used by M. Latinin, I. Rasputenko, the functional approach was N. Lipovskaya, S. Seryogin, the institutional approach was K. Vashchenko, N. Hrytsyak, V. Troshchinsky.

All these approaches are relevant, however, in our opinion, the most effective measure is the functioning of the Institute of Anti-Corruption Bodies, which systematically and gradually forms and implements anti-corruption policies, adjusts the main methods and mechanisms for preventing and combating corruption.

In this connection, the problem of systematic analysis of the functioning and development of newly created anti-corruption bodies of Ukraine is urgent. In addition, insufficiently studied cooperation and development of newly created anti-corruption bodies, in fact, it is the anti-corruption bodies that influence the emergence of civil society and the implementation of major reforms in the country.

Presenting main material. Anti-corruption policy is shaped and implemented in specific circumstances in a specific institutional environment. Becoming an integral part of economic and social institutions, it influences the existing institutionsand the possible directions and speed of change. The importance of institutions is manifested primarily in the demand for rights that allow a group of individuals to receive redistributive benefits, and offers of such rights. Institutional characteristics determine, on the one hand, the magnitude of corruption payments, because they shape the 
demand for rights and the level of competition among the possible owners of those rights, and on the other, the ability of an official to coordinate a corruption transaction

An important preventive factor in the fight against corruption is the improvement of anti-corruption bodies. More attention should be paid to timely response to reports from citizens, the media, the results of sociological research on corruption and other illegal actions of officials, the prevalence of corruption in individual agencies (Olentsevych N. et al., 2018, p. 28-33).

In 2015, the formation and development of the National Anti-Corruption Bureau of Ukraine begins. In addition, a Specialized Anti-Corruption Prosecutor's Office was formed within the structure of the Prosecutor General's Office of Ukraine.In accordance with the Law of Ukraine «On Prevention of Corruption», one of the key anti-corruption bodies - the National Agency for the Prevention of Corruption - started operating in 2016. So, during 2015-2016, major anti-corruption institutions were created.

At the same time, it should be noted that in Ukraine though anti-corruption bodies have been created, their activities are ineffective due to the lack of coordination mechanism, inefficient use of available resources, insufficient involvement of civil society to combat corruption.

In our opinion, the coordination of anti-corruption bodies can be summarized as follows (Figure 1).

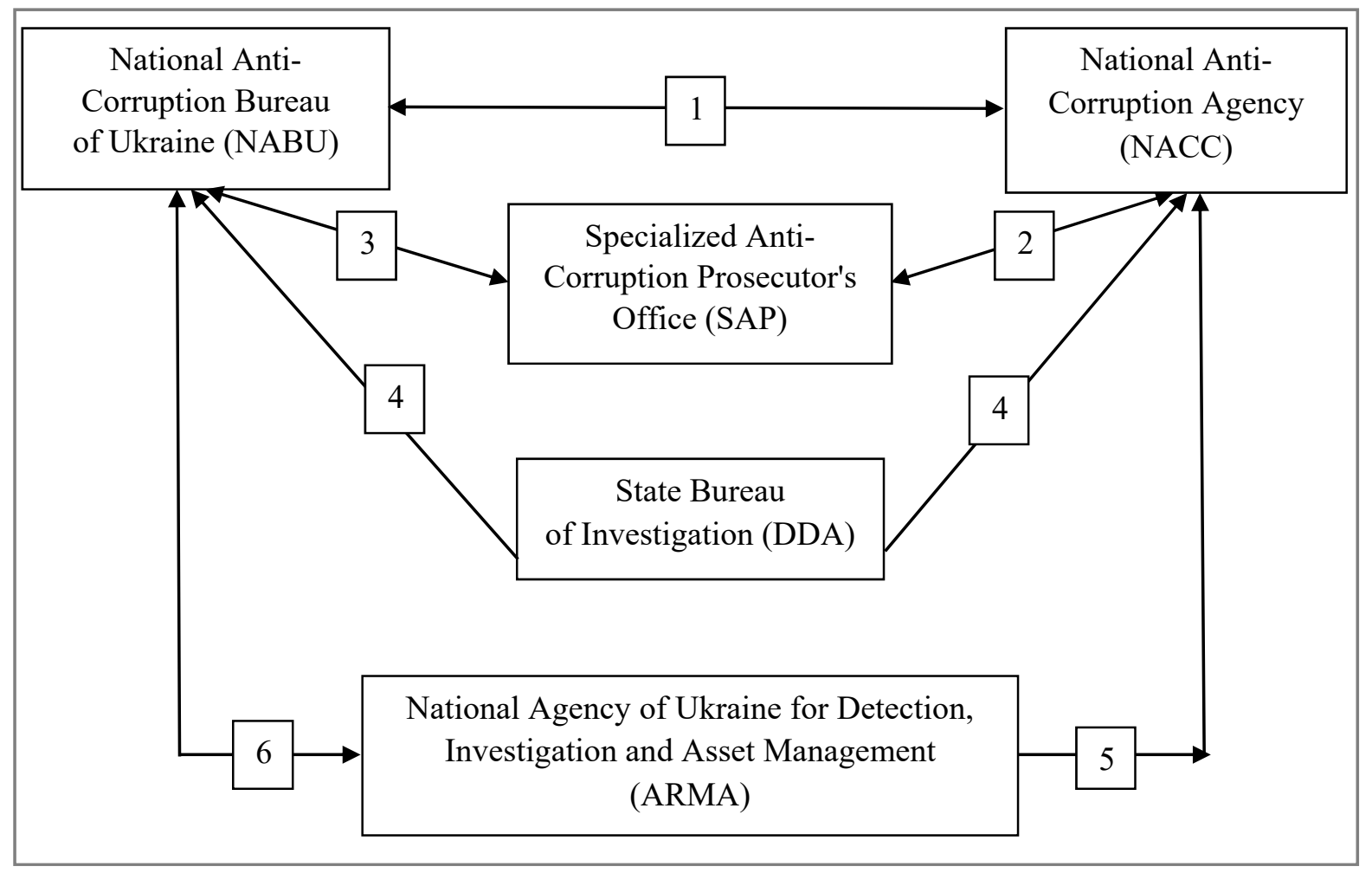

Figure 1. Mechanism of coordination of activities of anti-corruption bodies

Compiled by the author in (4, 9-15) 
1. NACC checks the declarations of civil servants, NABU directs requests for verification of declarationsindividuals and the investigation beginsafter full verification of the NAPC declarationю

2. The SAP is focusing its efforts on preventionand counteracting corruption and redressthe losses it caused; development, coordinationand implementation of joint NAPC activities; preparation of proposals for improvement of anti-corruption legislation.

3. coordination of SAP and NABU actions for attractionaccountability, further trial and punishment for corruption.

4. DDA conducts corruption crimescommitted by NABU officials, SAP.

5. ARMA provides the formation and implementationpublic policy on detection andthe search for assets that can be seized.

6. NABU is searching and seizing assets, who may be arrested; NAIA managesassets that have been seized or confiscated.

Table 1

Factors influencing the effectiveness of anti-corruption bodies

\begin{tabular}{|c|l|l|}
\hline № & \multicolumn{1}{|c|}{ Factor } & \multicolumn{1}{|c|}{ Feature } \\
\hline 1 & $\begin{array}{l}\text { Absence of specially trained specialists who will } \\
\text { implement anti-corruption policyand knowledgeable in } \\
\text { preventing and combating corruption and having the } \\
\text { appropriate qualifications and experience }\end{array}$ & $\begin{array}{l}\text { When selecting candidates for anti-corruption } \\
\text { positions, preference should be given to } \\
\text { candidates with a law or economic background } \\
\text { and previous work experience most closely } \\
\text { related to the prevention of corruption }\end{array}$ \\
\hline 2 & $\begin{array}{l}\text { Lack of experience of activity and institutional capacity } \\
\text { of these bodies, as these are newly created bodies that } \\
\text { shape their activities based on the experience of } \\
\text { European and world practices, which does not always } \\
\text { work in our country }\end{array}$ & $\begin{array}{l}\text { In Ukraine, the nature of corruption differs } \\
\text { from corruption in other countries, so the } \\
\text { mental features of corruption are to be taken } \\
\text { into account }\end{array}$ \\
\hline 3 & $\begin{array}{l}\text { Anti-corruption bodies have slowly started their activity } \\
\text { as their staff has been forming for a very long time }\end{array}$ & $\begin{array}{l}\text { The NACC has not been fully staffed for over a } \\
\text { year, and the staff of the ARMA received from } \\
\text { corruption and other crimes, as well as the } \\
\text { BDA, has not been fully staffed to date }\end{array}$ \\
\hline 4 & $\begin{array}{l}\text { There is no interaction of the mentioned anti-corruption } \\
\text { bodies, which should be regulated in the current } \\
\text { regulatory documents, while anti-corruption institutions } \\
\text { duplicate each other's activities }\end{array}$ & $\begin{array}{l}\text { This includes drafting administrative records, } \\
\text { overseeing compliance with declarations, and } \\
\text { conflicts of interest }\end{array}$ \\
\hline
\end{tabular}

By the author

In order to form unified anti-corruption bases, it is necessary to exchange information bases within the competence of the NABU, NAPC, and ARMA bodies.In addition, cooperation between the Specialized Anti-Corruption Prosecutor's Office and other anti-corruption bodies should be strengthened in order to establish databases of persons who have committed corruption or corruption-related offenses.Therefore, 
we conclude that the established anti-corruption organizations do not fulfill their tasks of preventing and combating corruption, therefore their activity is criticized by foreign experts and the public.As a result, it is urgent to systematize the role of these institutions, formulate priorities for the development of state anti-corruption policy, adopt systemic legislation on the implementation of anti-corruption policy, indicating the role of each anti-corruption body, criteria for its effectiveness and effectiveness of indicators of implementation of anti-corruption measures.Formation of joint and united activity of anti-corruption bodies is the basis of qualitative fight against corruption, minimization of its manifestations. These anti-corruption bodies should be in constant cooperation.

In addition, improving the existing anti-corruption measures is to eliminate the shortcomings of anti-corruption legislation that create the conditions for corrupt public relations.

As already mentioned, the fight against corruption today is one of the strategic foundations of Ukraine's state policy. Along with combating the negative impact of corruption on economic security, there is a need to put in place effective mechanisms for the return of corruption capital. This will have a positive impact on increasing the national economic potential, will contribute to the growth of the national economy and strengthen the economic security of Ukraine.

The fight against corruption, as with other institutional strains, must be complex. To counteract corruption, the executive branch, the parliament, business and the public should unite. The main anti-corruption factor should be the formation and implementation of «rules of the game» and conditions of equal competition. The state and the authorities should be the first to demonstrate the principle of the rule of law, which will greatly enhance the economic security of Ukraine.

The fight against corruption is a task not only for public authorities and local authorities, but also for civil society institutions. There is a need for a radical change in public consciousness, which will prove to be a climate of brutal rejection of corruption in the population, since the significant growth of corruption and its scale is the most acute problem of our state and society today.Corruption has become one of the main sources of destructive influence on the processes of social, economic and political development of Ukraine and threatens the stability of economic and financial institutions.

It should be said that in recent years there has been a change in priorities in the use of corruption by their corrupt officials. Previously, the goal was achieved mainly through bribery of government officials. Today, personal presence in the authorities or lobbying of their interests through the presence of their representatives is a priority.

What is important is that by analyzing the number of those responsible for corruption, we can conclude that, as a rule, corrupt officials with minor violations appear before the law, and elite groups endowed with power are inviolable. 
Thus, we conclude on the politicization of corruption, that is, the awareness of corrupt officials of their own political interests, which is different from the interests of other social strata.A corrupt person pursues not only an economic goal (gaining excess profits, control over certain sectors of the economy, regions, individual enterprises, etc.), but also political - gaining power to lobby for their interests, political support for corruption.Lobbying is one of the indicators of politicization of corruption and is implemented both with the help of corrupt officials holding public office and through bribery of other employees.

Corruption activity allows to acquire legal social status, as well as to legalize the proceeds of crime.It is a means of criminalizing power and politicizing corruption.Corrupt individuals are interested in creating appropriate positions in government structures to ensure favorable conditions for their unlawful activities and avoid legal liability, and to use financial, organizational and other opportunities in their unlawful activities.Increasing the number of corruption manifestations leads to an increase in the nature of their corruption, and their penetration into power contributes to its corruption.

The main purpose of corruption is to make a profit. Therefore, a corrupt person seeks to break into economic relations through the use of corruption mechanisms.

S. Rose-Ackerman as follows characterizes the mechanism of occurrence of corruption agreements in cases where the government acts as a buyer or contractor:the interested company may give a bribe to be included in the list of participants of the future tender and limit the number of its participants;it may pay for providing the insider with information;with the help of a bribe it is possible to define such conditions of the tender that the briber company is the only candidate that fully meets all the requirements; the company can buy a winning bid; by winning the contract, the company can bribe to change it in its favor [11].

Based on the study of political, economic, organizational, managerial, legal, ideological, moral-psychological and other factors of corruption, it is possible to reflect fundamental anti-corruption activities and related provisions that:- corruption is the product of not one or more, but a whole system of different in character, force of determinative influence and areas of manifestation of social preconditions, causes and conditions;- counteraction to corruption cannot be reduced to direct law enforcement activity, but represents a complex and continuous implementation of the state's anticorruption activity function;- counteraction to corruption will be effective if priority is given to the stage of prevention of corruption.

Recognizing the level (spread) of corruption as an indicator of institutional inefficiency as a negative factor in socio-economic development creates objective prerequisites for anti-corruption policies. It is defined as a set of sequential actions (actions) of the subjects of this policy (state bodies, non-profit organizations, economic entities, citizens) to existing and potential counterparties of corruption transactions, with the aim of reducing the level of corruption by reducing its 
comparative advantages. Therefore, effective anti-corruption policy involves the design and implementation of institutional changes.

Generalizing the international experience of anti-corruption policy is one of the tasks for many international and domestic organizations. Consistent with the position of domestic scientists, taking into account the approaches of V. Bashtannik, N. Lipovskaya, S. Seryogin, the following approaches should be followed in the process of forming anti-corruption policy (Table 2).

Table 2

\section{Basic approaches to anti-corruption policy}

\begin{tabular}{|l|l|}
\hline \multicolumn{1}{|c|}{ Approach } & \multicolumn{1}{c|}{ Content } \\
\hline System & $\begin{array}{l}\text { Revealing the impact of corruption on society, research disorganization and } \\
\text { reorganization effects of corruption }\end{array}$ \\
\hline Institutional & $\begin{array}{l}\text { Defining the system of anti-corruption organizations, the purpose activities } \\
\text { which are the prevention, counteraction and elimination of the negative the } \\
\text { consequences of corruption. }\end{array}$ \\
\hline Morphological & Description of forms and manifestations of corruption in the authorities \\
\hline Phenomenological & $\begin{array}{l}\text { For the study of subjective perception corruption, its socio-cultural, mental, } \\
\text { social, psychological backgrounds. }\end{array}$ \\
\hline Comparative & $\begin{array}{l}\text { Implementation of foreign experience of anti-corruption } \\
\text { policy,implementation of standards of international organizations in the field } \\
\text { of combating corruption. }\end{array}$ \\
\hline Empirical & Observations, modeling, surveys, expert assessments, statistics. \\
\hline
\end{tabular}

Compiled by [Ser'ohin S.et al., 2012], own research]

The generalization of the results of the application of anti-corruption programs is shown in Table 3.

Table 3

\section{Global experience in the effectiveness of anti-corruption programs}

\begin{tabular}{|c|l|l|}
\hline № & Anti-corruption measures & \multicolumn{1}{|c|}{ Generalized empirical effects data } \\
\hline 1 & $\begin{array}{l}\text { Creation of anti-corruption } \\
\text { institution }\end{array}$ & $\begin{array}{l}\text { Anti-corruption institutions have been successful in Chile, } \\
\text { Hong Kong, Australia and Singapore. However, officials } \\
\text { developing countries with high levels of corruption do not } \\
\text { see the potential benefits of this tool }\end{array}$ \\
\hline 2 & Opinion polls & $\begin{array}{l}\text { Opinion polls serve as a tool more accurate wording of the } \\
\text { public interest.International surveys highlight countries with } \\
\text { «chronic» corruption }\end{array}$ \\
\hline 3 & $\begin{array}{l}\text { Increasing the level of } \\
\text { remuneration in the public } \\
\text { sector }\end{array}$ & $\begin{array}{l}\text { Since corruption incomes are often revealed the dominant, } \\
\text { short-term effect of this no event was detected. Holding a } \\
\text { Corrupt Position associated with its «purchase», and increase } \\
\text { remuneration leads to an increase The «prices» of the } \\
\text { position being purchased }\end{array}$ \\
\hline
\end{tabular}




\begin{tabular}{|c|c|c|}
\hline № & Anti-corruption measures & Generalized empirical effects data \\
\hline 4 & State property reduction & $\begin{array}{l}\text { State Property Reduction in as a result, corruption is often } \\
\text { reduced, however, the privatization process itself can lead to } \\
\text { increased corruption }\end{array}$ \\
\hline 5 & $\begin{array}{l}\text { Increase accountability for } \\
\text { financial statements }\end{array}$ & Only a minor effect of reducing corruption was identified \\
\hline 6 & Independent Media (Media) & Increasing media independence means reducing corruption \\
\hline 7 & Independent judicial system & The independence of the judiciary clearly reduces corruption \\
\hline 8 & Active civil society & Citizens' activity also contributes to reducing corruption \\
\hline 9 & $\begin{array}{l}\text { Decentralization of decision } \\
\text { making }\end{array}$ & Decentralization also leads to a reduction in corruption \\
\hline 10 & $\begin{array}{l}\text { Standards of conduct of a } \\
\text { public servant }\end{array}$ & $\begin{array}{l}\text { Compliance with the standards of conduct of a civil servant } \\
\text { leads to a reduction in the level of corruption }\end{array}$ \\
\hline
\end{tabular}

Compiled by [Huther J. et al, 2000]

Based on Table 3, you canconclude that organizational-anti-corruption measures (measures 1, 3, 5) if they have, then it is insignificantpositive effect. However, the development of civil society institutions, their independence and independence can have a significant effect.

In the economy of transition is formedtransitional rent. Income fromparticipation in the restructuring of the economy, directlynot associated with increased production efficiency. One of the most important tasks of the initialStage of reform is the organization of withdrawaltransitional rent for the benefit of the state, acting for the benefit of society. However, in the implementation phase of the transitionprivatization of transition rents may occur. The loss of resources does not only occurdue to lack of economic coordinationagents, but also in connection with the exchange of power for the property.

To prevent such institutional pitfalls, you need to plan from the beginningthe gradual elimination of the institute, ineffective atthe long run where the norms are, the injected should be temporary andpredict your own automatic cancellation. corruption., which exist in all spheres

High latency and mimicry of corruptionmakes it inaccessible to control. At latent redistribution of public resourcesan illusory one is formed with the corruption componentconcept of economic stability. Soa form of response to latent corruptionmust be contained in mandatory anti-crisisand anti-corruption economic programs. When formingsuch programs need to be considered economic, organizational, sociopsychological causessocial relations and related to socialthat remain unresolved.

To overcome the institutional trap that has become institutional for our country corruption, necessary shock events that would violate persistent corruption relations.

For the effective functioning of anti-corruption policy institutional innovation is necessary. One is improvement anti-corruption organizations, in particular, the creation of special ones anti-corruption units aimed at countering elite corruption. It is 
also necessary to organize anti-corruption monitoring for regular detection the level of development of corruption in different areas of life based on statistical data and opinion polls.

Preventive action is needed to counteract corruption activities that can be developed only through comprehensive analysis and monitoring of threats to economic security. These are essential elements of effective implementation anti-corruption policies, the essence of which is in the development and implementation of the complex legal, organizational, economic, technical and other surveillance measures on corruption in priority industries for the purpose of adoption management decisions regarding security their economic security. With due organization of monitoring corruption. Monitoring identifies threats economic security, measures are being developed for them neutralization, thereby providing favorable conditions for the development of entrepreneurship and investment activities.

A microeconomic approach involves a sociological survey public opinion, macroeconomic - statistical analysis data. According to a certain list of macroeconomic indicators can track changes in corruption in individual regions and industries.

In our opinion, the criterion of efficiencysystems of state social, economic andpolitical institutions can advocate the formation of the middlea class characterized by: a high level of education, social and economic activity, availability of tangible assets that in the complex can promote development economic stability. In the period of modernization The middle class economy can also become a nucleus in the mechanism of development countries on purpose state support from representatives of this social group This factor is due to the fact that high standard of living, financial well-being promotes interest in social and the resulting political stability intensify the processes of democratic transformation in the country, and, as a consequence, reduce the level of corruption. The ability of the middle class to act as a carrier of the implementation of anti-corruption policy can be negative in this case splicing it with corruption. Thus in this way, the middle class is important role in stabilizing society, a can also become the main subject conducting anti-corruption reforms in the state.

Conclusion. Thus, the analysis was performed activities of anti-corruption organizations on prevention and anti-corruption permits summarize the most characteristic trends and mechanisms. The priorities here should be:

- anti-corruption education aimed at enhancement the level of civic consciousness and dissemination public perception of corruption as shameful phenomena through the introduction of anti-corruption education programs and projects;

- expanding the functions of civil society institutions, by providing them with monitoring functions and audit of anti-corruption policy;

- the advantage of preventive measures over repressive measures while improving performance employees of anti-corruption structures; ensuring non-avoidance punishment for all corrupt officials; legalization(following the US example) of the Lobby Institute both central and locally, which has to eliminate the corruption 
component in the representative(elective) bodies as the state, yes (more critical) and on local because official lobbying will promote greater openness and transparency public administration. According to A. Mykytchuk, «Our country is one of the most corrupt countries in the world, and its «successes» in this matter are ahead of the national economy, and we are also in the top ten corrupt countries ... Almost everyone faces corruption citizens, but they are and accordingly only 47 individual facts are punished which ultimately undermines the principle the inevitability of punishment» [Chernyavs'kyy Set al, 2017].

- creation of anticorruption receptions and direct ones telephone lines, widespread attraction of Internet resources to inform about facts of corruption cases; strict and unavoidable responsibility for not taking measures against corruption cases by anti-corruption bodies, for example National Anti-Corruption Bureau. In modern times The civilized world of the media is well regarded the main activity control tool authorities, and the «watch dogs of democracy» [Yong-sung You, 2015].

\section{REFERENCES}

1. Chernyavs'kyy S. Chekhlenko O., Kosenkova N., Khodzha I. (2017). Zapobihannya ta protydiya koruptsiyi [Prevention and counteraction to corruption] Kiev: Nats. akad. vnutr. Sprav, 120 p. Retrieved from: https://library.naiau.kiev.ua/ bibliografichni-pokazhchiki/zapobigannya-ta-protidiya-korupciyi-bibliografichnijpokazhchik.pdf [in Ukrainian].

2. Holmes L. Corruption: A Very Short Introduction / Leslie Holmes. - Oxford University Press, 2015. 144 p.

3. Huther J.\& Shah A. Anti-corruption Policies and Programs: A Framework for Evaluation. // World Bank: Policy Research Working Paper. No 2501, 2000. Retrieved from: http://documents.worldbank.org/curated/en/578241468767095005/ $\mathrm{pdf} /$ multi-page.pdf

4. Nakaz Heneral'noho prokurora Ukrayiny «Pro koordynatsiyu diyal'nosti pravookhoronnykh orhaniv u sferi protydiyi zlochynnosti ta koruptsiyi» № $1 / 1 \mathrm{hn}$ vid 16.01.2013 [Order of the Prosecutor General of Ukraine «On Coordination of Law Enforcement in the Sphere of Crime and Corruption»] (n.d.) zakon.rada.gov.ua. Retrieved from: https://zakon.rada.gov.ua/rada/show/v0001900-13 [in Ukrainian].

5. Olentsevych N. V. \& Fomina O. O. (2018). Koruptsiya v systemi publichnoho upravlinnya: prychyny ta zapobihannya [Corruption in Public Management: Causes and Prevention]. Biznes Inform, 11, 28-33. Retrieved from http://www.business-inform.net/export_pdf/business-inform-2018-11_0-pages-28_33.pdf [in Ukrainian]. 
6. Rose-Ackerman S. Corruption and Government: Causes, Consequences, and Reform [Text] / Susan Rose-Ackerman, Bonnie J. Palifka. - Cambridge: Cambridge University Press, 2016. 616 p.

7. Ser'ohin S., Bashtannyk V., Lypovs'ka N: Antykoruptsiyna polityka derzhavy: skladovi ta napryamky realizatsiyi. Dnipropetrovs'k, 2012. 478 p.

8. Yong-sung You. Democracy. Inequality and Corruption. Cambridge University Press, 2015. 308 p. Retrieved from:https://www.tandfonline.com/doi/abs/ 10.1080/00472336.2016.1208835

9. Zakon Ukrayiny «Pro Natsional'ne ahenstvo Ukrayiny z pytan' vyyavlennya, rozshuku ta upravlinnya aktyvamy, oderzhanymy vid koruptsiynykh ta inshykh zlochyniv» № 772-VIII vid 10.11.2015 [Law of Ukraine «On National Agency of Ukraine for Detection, Investigation and Management of Assets Received from Corruption and Other Crimes] (n.d.) zakon.rada.gov.ua. Retrieved from https://zakon.rada.gov.ua/laws/show/772-19 [in Ukrainian].

10. Zakon Ukrayiny «Pro prokuraturu» № 1679-VII vid 14.10.2014 [Law of Ukraine «On the Prosecutor's Office»] (n.d.) zakon.rada.gov.ua. Retrieved from http://zakon.rada.gov.ua/laws/show/1697-18 [in Ukrainian].

11. Zakon Ukrayiny «Pro Natsional'ne antykoruptsiyne byuro Ukrayiny» № 1698-VII. vid 14.102014 [Law of Ukraine «On the National Anti-Corruption Bureau of Ukraine»] (n.d.) zakon.rada.gov.ua. Retrieved from http://zakon0.rada.gov. ua/laws/show/1698-18 [in Ukrainian].

12. Zakon Ukrayiny «Pro zapobihannya koruptsiyi» № 1700-VII vid 14.10.2014 [Law of Ukraine «On Prevention of Corruption»] (n.d.) zakon.rada.gov.ua. Retrieved from http://zakon0.rada.gov.ua/laws/show/1700-18 [in Ukrainian].

13. Zakon Ukrayiny «Pro Derzhavne byuro rozsliduvan'» № 794-VIII vid 12.11.2015 [Law of Ukraine «On the State Bureau of Investigation»] (n.d.) zakon.rada.gov.ua. Retrieved from http://zakon3.rada.gov.ua/laws/show/794-19 [in Ukrainian].

14. Zakon Ukrayiny «Pro vyshchyy antykoruptsiynyy sud» № 2447-VIII vid 07.06.2018 [Law of Ukraine «On the Supreme Anticorruption Court»] (n.d.) zakon.rada.gov.ua. Retrieved from: http://zakon0.rada.gov.ua/laws/show/2447-19 [in Ukrainian].

15. Zakon Ukrayiny «Pro Natsional'ne ahent'stvo Ukrayiny $\mathrm{z}$ pytan' vyyavlennya, rozshuku ta upravlinnya aktyvamy, oderzhanymy vid koruptsiynykh ta inshykh zlochyniv» № 772-VIII vid 10.11.2015 [Law of Ukraine «On National Agency of Ukraine for Detection, Investigation and Management of Assets Received from Corruption and Other Crimes»] (n.d.) zakon.rada.gov.ua. Retrieved from: http://zakon2.rada.gov.ua/laws/show/772-19 [in Ukrainian]. 